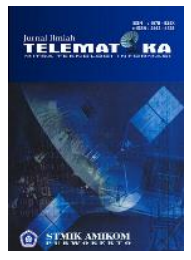

Terbit online pada laman web jurnal

http://ejournal.amikompurwokerto.ac.id/index.php/telematikal

Telematika

\title{
Penerapan Metode SMART untuk Seleksi Kelayakan Penerima Bantuan Pengembangan Usaha Pangan Masyarakat
}

\author{
Mohammad Guntur'1, Robi Yanto ${ }^{2}$
}

${ }^{1,2}$ Sistem Informasi

STMIK Bina Nusantara Jaya Lubuklinggau

Email : gunturmuhammad23@gmail.com ${ }^{1}$, wrtech30@gmail.com ${ }^{2}$

\section{INFO ART IKEL \\ Sejarah artikel: \\ Menerima 3 Mei 2019 \\ Revisi 28 Juni 2019 \\ Diterima 29 Agustus 2019 \\ Online Agustus 2019 \\ Kata kunci: \\ Sistem Pendukung Keputusan, \\ SMART, \\ Bantuan, \\ Pangan.}

Keywords:

Decision Support Systems,

SMART

Help,

Food.

Korespondensi:

Telepon: +62 85267188007

E-mail:

wrtech30@gmail.com

\begin{abstract}
ABSTRAK
Kegiatan pengembangan usaha pangan masyarakat merupakan kegiatan yang digunakan untuk memperkuat permodalan dan untuk menyerap gabah yang diproduksi petani dengan harga minimal dan dapat berperan menjaga keseimbangan harga disaat panen raya. Kegiatan dilakukan melalui pemberian dana bantuan untuk gabungan kelompok tani. Dinas Ketahanan Pangan Kota Lubuklinggau, dalam proses pengambilan keputusan pemilihan penerima bantuan pengembangan usaha pangan masyarakat saat ini dilakukan berdasarkan penilaian terhadap data yang telah dilengkapi oleh kelompok tani tanpa mempertimbangkan nilai dari setiap kriteria yang ada, mengakibatkan hasil penilaian tidak tepat dan cenderung bersifat subjektif. maka dari itu perlu dibangun sistem pendukung keputusan yang bertujuan untuk membantu menyelesaikan masalah seleksi pemberian bantuan dana pengembangan usaha pangan masyarakat agar tepat sasaran, adapun metode yang digunakan adalah metode SMART dimana metode ini mampu melakukan proses perangkingan terhadap alternatif dengan kritieria yang telah dipilih sebagai hasil penilaian berdasarkan kebutuhan seleksi yaitu Legalitas, pengalaman kegiatan dagang, memiliki AD/ART, mesin penggiling dan luas gudang penyimpanan. Hasil dari analisa menggunakan metode SMART dengan memperhatikan kriteria yang dipilih diketahui bahwa kelompok tani yang sangat layak untuk menerima bantuan pengembangan usaha pangan adalah kelompok tani rukun tani dengan bobot nilai 94, sedangkan rekomendasi layak dan dipertimbangkan adalah kelompok tani karya bersama dan kelompok tani usaha mandiri dengan bobot nilai masing masing yaitu 82,75 dan 74 . Sehingga dari hasil analisa menggunakan metode SMART dapat membantu pihak pengambil keputusan dalam memilih keompok tani yang layak menerima bantuan pengembangan usaha pangan masyarakat dengan tepat dan objektif.
\end{abstract}


and consideration are joint farmer groups and independent business farmer groups with the values of each are 82.75 and 74. So that from the analysis using the SMART method can help decision-makers in selecting farmer groups that are eligible to receive assistance in developing community food business appropriately and objectively.

\section{PENDAHULUAN}

Teknologi informasi merupakan media yang dapat mempermudah manusia dalam melakukan pekerjaannya secara efektif dan efisien. Sehingga teknologi sangat diperlukan untuk memperoleh informasi dan sebagai media bagi pimpinan dalam mengambil keputusan. Salah satu perkembangan teknologi yang semakin pesat adalah penerapan teknologi pada hampir disemua bidang kerja, dikarenakan dapat mengolah data dengan cepat dan tepat sehingga menghasilkan informasi sebagai sumber dalam menentukan keputusan.

Menurut Aziz (2018), Pengembangan Usaha Pangan Masyarakat atau PUPM adalah kegiatan memberdayakan gabungan kelompok tani untuk menjaga keseimbangan supplay dan harga pangan. Tujuan dari Program Pengembangan Usaha Pangan Masyarakat (PUPM) yaitu menyerap produk pertanian nasional dengan harga yang layak dan menguntungkan petani khususnya pada bahan pangan pokok, serta mendukung stabilisasi pasokan harga pangan pokok, dan memberikan masyarakat dalam mengakses bahan pangan pokok, dengan harga yang terjangkau.

Dalam pedoman pelaksanaan PUPM, (2016) disebutkan bahwa Dalam upaya menyerap produk pertanian nasional dengan harga yang layak dan menguntungkan dan kemudahan akses konsumen atau masyarakat dengan harga terjangkau terhadap harga pangan pokok dan strategis, maka dilaksanakannya kegiatan pengembangan usaha pangan masyarakat (PUPM). Bantuan pengembangan usaha pangan masyarakat yang diberikan kepada gabungan kelompok tani merupakan kegiatan yang digunakan untuk memperkuat permodalan dan untuk menyerap gabah yang diproduksi petani dengan harga minimal sama dengan harga pangan pokok sehingga Gabungan Kelompok Tani dapat berperan dalam mewujudkan keseimbangan harga ditingkat petani. Dimana dalam proses pemilihan penerima bantuan pengembangan usaha pangan masyarakat yang saat ini dilakukan berdasarkan penilaian terhadap data yang telah dilengkapi oleh gabungan kelompok tani tanpa mempertimbangkan nilai nilai dari kriteria yang ada, sehingga penyaluran bantuan pengembangan usaha pangan kurang tepat sasaran maka dari itu dibutuhkan sistem pendukung keputusan seleksi kelayakan bagi penenerima bantuan pengembangan usaha untuk menghindari kesalahan dalam proses perhitungan bobot kriteria.

Untuk membantu menyelesaikan masalah tersebut diperlukan suatu sistem pendukung keputusan seleksi penerimaan bantuan yang tepat dan obektif. Menurut Arni (2019), Sistem Pendukung Keputusan adalah sistem informasi interaktif yang menyediakan informasi, pemodelan dan proses manipulasi data yang digunakan untuk membuat pengambilan keputusan pada situasi yang semi terstruktur tanpa diketahui secara pasti bagaimana keputusan seharusnya dibuat. Menurut Yanto (2019), Sistem pendukung keputusan adalah teknik dalam pengambilan keputusan secara semi terstruktur dan tidak terstruktur melalui penerapan data dan model yang tersedia. Sedangkan menurut Mesran (2018), sistem pendukung keputusan merupakan bagian dari sistem komputer yang bertujuan untuk proses peningkatan efektifitas dalam menentukan keputusan. 
Menurut Novianti (2016), metode Simple Multi Attribute Rating Technique sebagai alat bantu pemilihan kriteria-kriteria secara obyektif sehingga mampu mengurangi kesalahan dalam proses pemilihan. Sedangkan Menurut Saputra (2019), cara kerja metode SMART berdasarkan pada setiap alternatif dari sejumlah kriteria yang memiliki nilai dan setiap kriteria memiliki bobot untuk mengetahui seberapa penting nilai kriteria terhadap kriteria yang lain. Dengan adanya pemilihan kriteria secara jelas dan sistematis, maka keterbukaan terhadap proses pemilihan penerima bantuan pengembangan usaha pangan masyarakat dapat dilakukan secara tepat dan objektif.

Berdasarkan analisa dari penelitian terdahulu sebagai perbandingan yaitu penelitian yang dilakukan oleh Sesnika (2016), yaitu Aplikasi Sistem Pendukung Keputusan Pemilihan Gedung Serba Guna Menggunakan Metode Smart Berbasis Android berdasarkan kriteria yaitu harga sewa, kapasitas gedung, fasilitas gedung, jenis gedung, tujuan acara, waktu peminjaman, dan lahan parkir. Penelitian selanjutnya dilakukan oleh faizal (2017), yaitu penerapan Metode SMART untuk Merangking Kemiskinan dalam Proses Penentuan Penerima Bantuan program keluarga harapan dengan kriteria luas bangunan, jenis lantai, jenis dinding, fasilitas mck, penerangan, sumber air bersih, bahan bakar memasak, konsumsi, membeli pakaian, makan sehari, biaya pengobatan, penghasilan, pendidikan krt, jumlah tabungan, ibu hamil/nifas, anak balita, anak SD, anak smp, anak 6-12 tahun.

Penelitian sejenis juga dilakukan oleh Santosa (2017), tentang Sistem Pendukung Keputusan Pemilihan Sekolah Paud dengan metode SMART dengan kriteria biaya, fasilitas, kurikulum, kualitas sekolah dan jarak. Sedangkan menurut Cholil (2018) tentang implementasi simple multi attribute rating technique untuk penentuan prioritas rehabilitasi dan rekonstruksi pasca bencana alam dengan kriteria kemanusiaan, perumahan, infrastruktur, social, ekonomi dan lintas sector.

Penelitian budiman (2013) berjudul sistem penunjang keputusan anggota kepolisian terhadap calon Seleksi Alin Golongan (SAG) menggunakan Metode SMART, teknik pengambilan keputusan multi kriteria ini didasarkan setiap alternatif terdiri dari beberapa kriteria yang memiliki nilai dan setiap kriteria memiliki bobot sesuai dengan tingkat kepentingan yang dibandingkan terhadap kriteria lain yang digunakan untuk menilai dalam memperoleh alternatif terbaik dalam proses.

Berdasarkan hasil analisa dari penelitian terdahulu terdapat kesamaan pada metode yang digunakan untuk melakukan proses pemilihan atau seleksi dengan proses perangkingan yaitu dengan menggunakan metode SMART. Kriteria yang digunakan untuk penelitian ini diperoleh berdasarkan hasil wawancara dari pihak Kantor Ketahanan Pangan Kota Lubuklinggau.

\section{METODE PENELITIAN}

Metode pemecahan masalah yang digunakan pada penelitian ini adalah metode Simple Multi Attribut Rating Technique menurut karena metode ini menerapkan proses penilaian banyak kriteria untuk menghasilkan perangkingan terhadap penilaian terbaik sesuai dengan nilai rekomendasi. Menurut sukmawati (2016), penelitian kuantitatif adalah teknik dalam melakukan kajian empiris untuk mengumpulkan, mengalisa, dan menampilkan data dalam bentuk numerik. Pada penelitian ini menggunakan metode penelitian kuantitatif. Adapun tahapan penelitian seperti pada gambar 1 . 


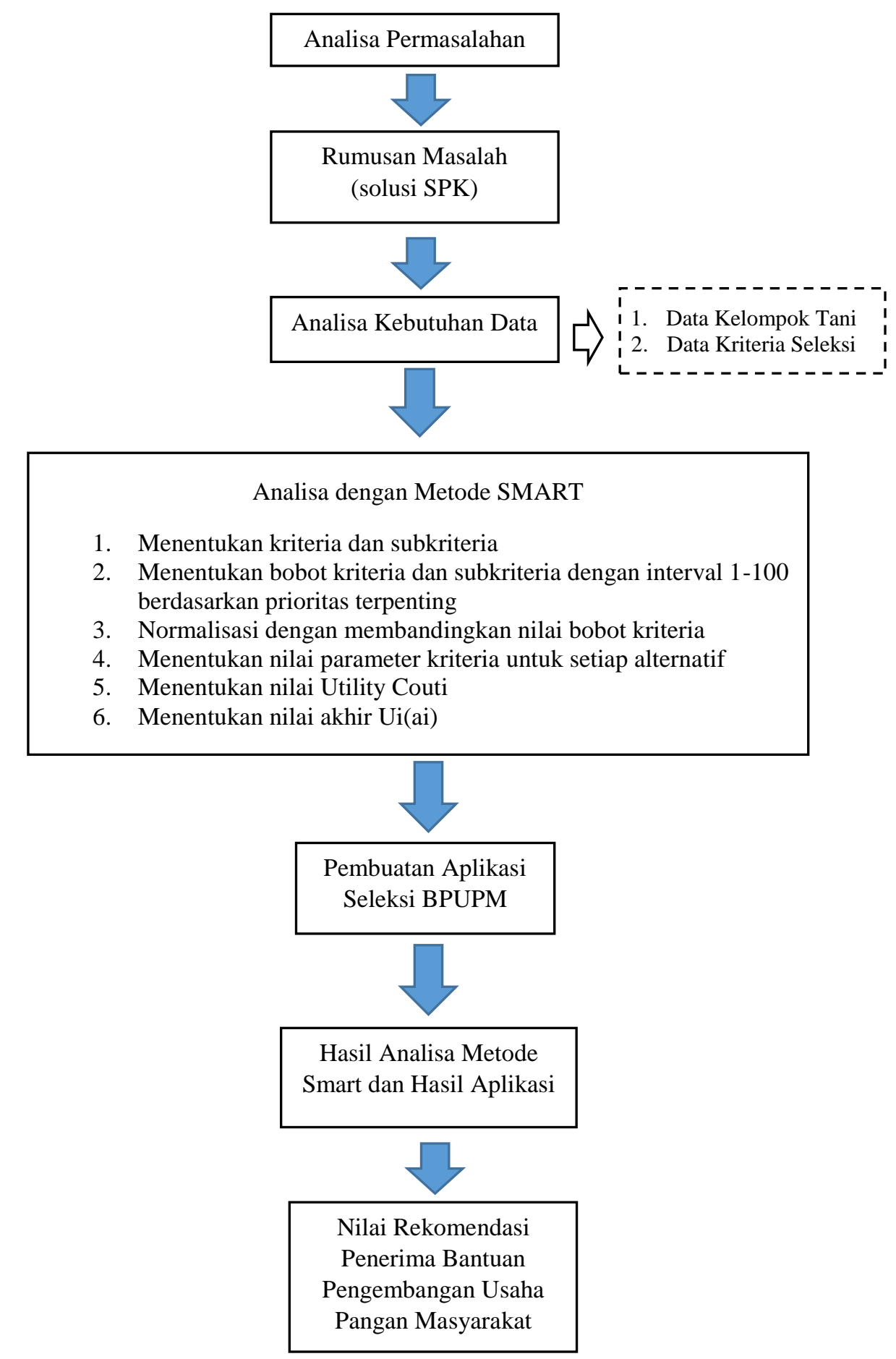

Gambar 1. Tahapan Penelitian

\section{HASIL DAN PEMBAHASAN}

Pemilihan data alternatif merupakan data kelompok tani yang akan dijadikan data kelayakan seleksi penerima bantuan usaha pangan masyarakat. Data gabungan kelompok tani diperoleh berdasarkan hasil observasi yang dilakukan pada kantor ketahanan Pangan Kota Lubuklinggau melalui dokumen peraturan daerah kota lubuklinggau tahun 2012 seperti pada table 1. 
Tabel 1. Data Gabungan Kelompok Tani

\begin{tabular}{l}
\hline Gabungan Kelompok Tani Karya Bersama \\
\hline Ketua : Wasino $\quad$ Bendahara : M. Jahidin \\
\hline Sekretaris : Sangkut $\quad$ Alamat : Kel Petanang \\
\hline Kelompok Tani \\
\hline 1. Kotan Unggul Karya \\
2. Kotan Harapan Mulya \\
3. Kotan Bangun \\
4. Kotan Sidomaju \\
5. Kotan Karya Usaha \\
\hline Gabungan Kelompok Tani Usaha Mandiri \\
\hline Ketua : DediMaherijaya Bendahara : A. Gofar \\
\hline Sekretaris : Suryana $\quad$ Alamat :Kel Eka Marga \\
\hline Kelompok Tani \\
1. Kotan Burjaya I \\
2. Kotan Burjaya II \\
3. Kotan Harapan \\
\hline Gabungan Kelompok Tani Rukun Tani \\
\hline Ketua : Kaswadi \\
\hline Sekretaris : Subawi $\quad$ Alamat :Kel Margerejo \\
\hline Kelompok Tani \\
\hline 1. Kotan Cipta karya \\
2. Kotan Gemah Ripah \\
3. Kotan Kustur \\
4. Kotan Harapan Jaya \\
5. Kotan Jawi \\
6. Kotan Sri Lestari \\
7. Kotan Rukun sentosa \\
\hline
\end{tabular}

Data penerima bantuan pengembangan usaha pangan masyarakat yang berjumlah 3 kelompok tani dan blanko isian pedaftaran kelompok tani. Data yang dikumpulkan sebagai bahan analisa dalam penentuan kriteria yang tepat untuk kelayakan pemberian bantuan usaha kepada kelompok tani.

\section{Menentukan Kriteria dan Bobot}

Kriteria dan bobot diperoleh berdasarkan data kelompok tani yang ada pada kantor ketahanan pangan kota lubuklinggau. Untuk penentuan bobot kriteria dilihat dari skala prioritas persyaratan yang dijadikan dasar penilaian penerima bantuan, kemudian digunakan dalam proses perhitungan pemberian bantuan usaha pangan masyarakat berdasarkan tingkat kepentingan dari kriteria yang dipilih seperti pada tabel 2 sebagai berikut.

\section{Tabel 2. Bobot Kriteria}

\begin{tabular}{ccc}
\hline No & Kriteria & Bobot \\
\hline $\mathbf{1}$ & Legalitas & $30 \%$ \\
\hline $\mathbf{2}$ & Pengalaman Kegiatan Dagang & $40 \%$ \\
\hline $\mathbf{3}$ & Memiliki AD/ART & $15 \%$ \\
\hline $\mathbf{4}$ & Ketersedian Mesin & $10 \%$ \\
\hline $\mathbf{5}$ & Luas Gudang Penyimpanan & $5 \%$ \\
\hline \multicolumn{3}{c}{ Jumlah } \\
\hline
\end{tabular}

\section{Menentukan Normalisasi Bobot Kriteria}

Proses normalisasi bobot dilakukan untuk dapat melakukan proses perhitungan nilai utility pada setiap alternatif. Normalisasi bobot kriteria dapat dilakukan dengan menggunakan persamaan ke-1 sehingga didapatkan hasil normalisasi bobot seperti pada tabel 3 sebagai berikut : 
Tabel 3. Normalisasi Bobot Kriteria

\begin{tabular}{llll}
\hline No & Kriteria & Normalisasi \\
\hline $\mathbf{1}$ & Legalitas & 0.3 \\
\hline $\mathbf{2}$ & $\begin{array}{l}\text { Pengalaman Kegiatan } \\
\text { Dagang }\end{array}$ & 0.4 \\
\hline $\mathbf{3}$ & Memiliki AD/ART & 0.15 \\
\hline $\mathbf{4}$ & Ketersedian Mesin & 0.1 \\
\hline $\mathbf{5}$ & Luas Gudang Penyimpanan & 0.05 \\
\hline
\end{tabular}

\section{Menentukan Nilai Utility untuk Setiap Alternatif}

Proses perhitungan dalam menentukan nilai utility dilakukan dengan menggunakan persamaan rumus ke-2 Untuk melakukan proses masukan nilai pada kriteria dilakukan proses penentuan nilai utility masing-masing kriteria seperti pada tabel 4 sebagai berikut.

Tabel 4. Nilai Utility Setiap Alternatif

\begin{tabular}{|c|c|c|c|}
\hline No & Kriteria & Sub Kriteria & $\begin{array}{c}\text { Input Cou } \\
\text { i }\end{array}$ \\
\hline \multirow[t]{2}{*}{1} & \multirow[t]{2}{*}{ Legalitas } & Ada & 1 \\
\hline & & Tidak Ada & 5.5 \\
\hline \multirow[t]{4}{*}{2} & \multirow{4}{*}{$\begin{array}{c}\text { Pengalaman } \\
\text { Kegiatan } \\
\text { Dagang }\end{array}$} & $10-20$ tahun & 1 \\
\hline & & $5-10$ tahun & 3.2 \\
\hline & & 2- 5 Tahun & 5.5 \\
\hline & & $<2$ Tahun & 7.75 \\
\hline \multirow[t]{3}{*}{3} & \multirow{3}{*}{$\begin{array}{l}\text { Memiliki } \\
\text { AD/ART }\end{array}$} & Lengkap & 1 \\
\hline & & Tidak Lengkap & 4.6 \\
\hline & & Tidak Ada & 7.75 \\
\hline \multirow[t]{2}{*}{4} & \multirow{2}{*}{$\begin{array}{c}\text { Ketersediaan } \\
\text { Mesin }\end{array}$} & Ada & 1 \\
\hline & & Tidak Ada & 5.5 \\
\hline \multirow[t]{4}{*}{5} & \multirow{4}{*}{$\begin{array}{l}\text { Luas Gudang } \\
\text { Penyimpanan }\end{array}$} & $250-500 \mathrm{M}^{2}$ & 1 \\
\hline & & $100-250 \mathrm{M}^{2}$ & 3.2 \\
\hline & & $50-100 \mathrm{M}^{2}$ & 5.5 \\
\hline & & $<50 \mathrm{M}^{2}$ & 7.75 \\
\hline
\end{tabular}

\section{Hasil Nilai Utility}

Dilakukan penentuan nilai Cmax dan Cmin. Adapun nilai Cmax dan Cmin dapat diketahui melalui nilai input cout $\mathrm{i}$ yaitu nilai maksimal 10 dan minimal 1 . Maka hasil nilai utility dapat diperoleh dengan menggunakan persamaan rumus ke-2 dengan hasil sebagai berikut :

a. Kriteria Legalitas

Subkriteria ada $=100((10-1)) /((10-1)) \%=100$

Subkriteria tidak ada $=100((10-5.5)) /((10-1)) \%=50$

b. Kriteria Pengalaman Kegiatan Dagang

Subkriteria 10-20Tahun=100 $((10-1)) /((10-1)) \%=100$

Subkriteria 5-10Tahun $=100((10-3.2)) /((10-1)) \%=75$

Subkriteria 2-5 Tahun $=100((10-5.5)) /((10-1)) \%=50$

Subkriteria $<2$ Tahun $=100((10-7.75)) /((10-1)) \%=25$

c. Kriteria memilik AD/ART

Subkriteria lengkap $=100((10-1)) /((10-1)) \%=100$

Subkriteria tidaklengkap $=100((10-4.6)) /((10-1)) \%=60$

Subkriteria tidak ada $=100((10-7.75)) /((10-1)) \%=25$ 
d. Kriteria Ketersediaan Mesin

Subkriteria ada $=100((10-1)) /((10-1)) \%=100$

Subkriteria tidak ada $=100((10-5.5)) /((10-1)) \%=50$

e. Kriteria Luas Gudang Penyimpanan

Subkriteria $250-500 \mathrm{M} 2=100((10-1)) /((10-1)) \%=100$

Subkriteria 100-250 M2 =100((10-3.2))/((10-1))\% $=75$

Subkriteria 50-100 M2 =100 ((10-5.5))/((10-1) )\% $=50$

Subkriteria $<50$ M2 $=100((10-7.75)) /((10-1)) \%=25$

Menentukan hasil rekomendasi terhadap nilai yang diperoleh dari perhitungan menggunakan metode SMART dalam pemilihan penerima bantuan pengembangan usaha pangan masyarakat seperti pada tabel 5 dimana nilai rekomendasi diperoleh berdasarkan hasil wawancara berdasarkan pertanyaan-pertanyaan yang terstruktur.

Tabel 5. Rekomendasi Nilai

\begin{tabular}{lll}
\hline No & Nilai Akhir & Rekomendasi \\
\hline $\mathbf{1}$ & 0 Sampai 64 & Tidak Layak \\
\hline $\mathbf{2}$ & 65 Sampai 74 & Dipertimbangkan \\
\hline $\mathbf{3}$ & 75 Sampai 84 & Layak \\
\hline 4 & 85 Sampai 100 & Sangat Layak \\
\hline
\end{tabular}

\section{Hasil Perhitungan}

Proses perhitungan dilakukan dengan menggunakan data sampel sebanyak 3 kelompok tani yang dipilih secara acak. Untuk perhitungan nilai rekomendasi yaitu nilai utlility yang telah diperoleh dikali dengan bobot kriteria sehingga memperoleh nilai akhir yang ditotalkan dari semua nilai kriteria. Hasil tersebut dijadikan nilai rekomendasi terhadap alternatif yang akan dipilih sesuai dengan range rekomendasi nilai. Adapun hasil perhitungan berdasarkan alternatif atau kelompok tani yang ada seperti pada tabel 6, 7, 8 menggunakan persamaan ke-3 dan 4 sebagai berikut:

Tabel 6. Gabungan Kelompok Tani Karya Bersama

\begin{tabular}{|c|c|c|c|c|}
\hline \multirow[t]{2}{*}{ Kriteria } & \multicolumn{2}{|c|}{ Nilai Utility } & \multirow[t]{2}{*}{ Nilai Akhir } & \multirow[t]{2}{*}{ Rekomendasi } \\
\hline & Nilai & Hasil & & \\
\hline Legalitas & Ada & $100 \times 0,3$ & 30 & \multirow{6}{*}{ LAYAK } \\
\hline $\begin{array}{l}\text { Pengalaman } \\
\text { Kegiatan Dagang }\end{array}$ & $\begin{array}{l}5-10 \\
\text { Tahun }\end{array}$ & $75 \times 0,4$ & 30 & \\
\hline $\begin{array}{l}\text { Memiliki } \\
\text { AD/ART }\end{array}$ & $\begin{array}{l}\text { Tidak } \\
\text { Lengkap }\end{array}$ & $60 \times 0,15$ & 9 & \\
\hline $\begin{array}{l}\text { Ketersedian } \\
\text { Mesin }\end{array}$ & Ada & $100 \times 0,1$ & 10 & \\
\hline $\begin{array}{l}\text { Luas Gudang } \\
\text { Penyimpanan }\end{array}$ & $\begin{array}{l}100-250 \\
M^{2}\end{array}$ & $75 \times 0,05$ & 3,75 & \\
\hline Total & & & 82,75 & \\
\hline
\end{tabular}

Tabel 7. Gabungan Kelompok Tani Usaha Mandiri

\begin{tabular}{lllll}
\hline \multirow{2}{*}{ Kriteria } & \multicolumn{2}{c}{ Nilai Utility } & Nilai Akhir & Rekomendasi \\
\cline { 2 - 3 } & Nilai & Hasil & \\
\hline Legalitas & Ada & $100 \mathrm{x} 0,3$ & 30 & DIPERTIMBANGKAN \\
\hline $\begin{array}{l}\text { Pengalaman } \\
\text { Kegiatan Dagang }\end{array}$ & $2-5$ Tahun & $50 \mathrm{x} 0,4$ & 20 & \\
\hline
\end{tabular}




\begin{tabular}{llll}
\hline $\begin{array}{l}\text { Memiliki } \\
\text { AD/ART }\end{array}$ & Tidan & $60 \times 0,15$ & 9 \\
$\begin{array}{l}\text { Ketersedian } \\
\text { Mesin }\end{array}$ & Ada & $100 \times 0,1$ & 10 \\
\hline $\begin{array}{l}\text { Luas Gudang } \\
\text { Penyimpanan }\end{array}$ & $250-500 \mathrm{M}^{2}$ & $100 \times 0,05$ & 5 \\
\hline Total & & $\mathbf{7 4}$ \\
\hline
\end{tabular}

Tabel 8. Gabungan Kelompok Tani Rukun Tani

\begin{tabular}{|c|c|c|c|c|}
\hline \multirow[t]{2}{*}{ Kriteria } & \multicolumn{2}{|c|}{ Nilai Utility } & \multirow[t]{2}{*}{ Nilai Akhir } & \multirow[t]{2}{*}{ Rekomendasi } \\
\hline & Nilai & Hasil & & \\
\hline Legalitas & Ada & $100 \times 0,3$ & 30 & \multirow{6}{*}{ SANGAT LAYAK } \\
\hline $\begin{array}{l}\text { Pengalaman } \\
\text { Kegiatan Dagang }\end{array}$ & 10-20 Tahun & $100 \times 0,4$ & 40 & \\
\hline Memiliki AD/ART & $\begin{array}{l}\text { Tidak } \\
\text { Lengkap }\end{array}$ & $60 \times 0,15$ & 9 & \\
\hline Ketersedian Mesin & Ada & $100 x 0,1$ & 10 & \\
\hline $\begin{array}{l}\text { Luas Gudang } \\
\text { Penyimpanan }\end{array}$ & $250-500 \mathrm{M}^{2}$ & $100 x 0,05$ & 5 & \\
\hline Total & & & 94 & \\
\hline
\end{tabular}

Hasil rekomendasi ditentukan dengan kategori sangat layak jika nilai akhir >= 85, layak jika nilai akhir $>=75$, dipertimbangkan jika nilai akhir $>=65$ dan tidak layak jika nilai $<65$. Dilihat dari nilai akhir perhitungan untuk rekomendasi yang sangat layak untuk memperoleh bantuan dana pengembangan usaha pangan masyarakat adalah Gabungan Kelompok Tani Rukun Tani dengan nilai akhir rekomendasi 94.

Dari tahapan analisis data selanjutnya dilakukan pengembangan sistem. adapun Pada tahapan perancangan sistem menggunakan model perancangan data flow diagram (DFD) dan pada tahap perancangan basis data menggunakan model ER, untuk bahasa pemrograman yang digunakan adalan Bahasa pemrograman PHP sebagai alat bantu dalam pengambilan keputusan seleksi kelayakan penerima bantuan pengembangan usaha pangan masyarakat seperti pada gambar 1 - 3 .

\begin{tabular}{|c|c|c|c|c|}
\hline Kriter & & & & Tambah \\
\hline Show 1 & 10 entries & \multicolumn{2}{|r|}{ Search: } & \\
\hline ID $\uparrow$ & Kriteria & Bobot & \multicolumn{2}{|l|}{ Aksi } \\
\hline 1 & Legalitas & 0.3 & Edit & ®Hapus \\
\hline 2 & Pengalaman Kegiatan Dagang & 0.4 & Edit & ( Hapus \\
\hline 3 & Memiliki AD/ART & 0.15 & Edit & ®Hapus \\
\hline 4 & Ketersediaan Mesin & 0.1 & Edit & ( Hapus \\
\hline 5 & Luas Gudang Penyimpanan & 0.05 & Edit & ® Hapus \\
\hline \multicolumn{2}{|c|}{\begin{tabular}{l|l|l} 
Previous & 1 & Next
\end{tabular}} & \multicolumn{3}{|c|}{ Showing 1 to 5 of 5 entries } \\
\hline
\end{tabular}

Gambar 2. Data Kriteria

Pada gambar 1 dimana data kriteria dan bobot kriteria diolah berdasarkan data kriteria yang telah dipilih untuk kelayakan seleksi penerima bantuan pengembangan usaha pangan masyarakat 


\begin{tabular}{|c|c|c|c|}
\hline \multicolumn{3}{|c|}{ Sub Kriteria } & Tambah \\
\hline Show & 10 entries & \multicolumn{2}{|c|}{ Search: } \\
\hline No† & Kriteria & Sub Kriteria & \\
\hline 1 & Legalitas & $\begin{array}{l}100 \text { Ada } \\
50 \text { Tidak Ada } \otimes\end{array}$ & \\
\hline 2 & Pengalaman Kegiatan Dagang & $\begin{array}{l}100 \text { 10-20 Tahun } \otimes \\
502-5 \text { Tahun } \otimes \\
25<2 \text { tahun } \otimes \\
75-10 \text { Tahun } \otimes\end{array}$ & \\
\hline 3 & Memiliki AD/ART & $\begin{array}{l}100 \text { Lengkap } \circledast \\
60 \text { Tidak Lengkap } \\
25 \text { Tidak Ada }\end{array}$ & \\
\hline 4 & Ketersediaan Mesin & $\begin{array}{l}100 \text { Ada } \\
50 \text { Tidak Ada } \otimes\end{array}$ & \\
\hline 5 & Luas Gudang Penyimpanan & $\begin{array}{l}100250-500 \mathrm{M}{ }^{\otimes} \\
75100-250 \mathrm{M} \\
5050-100 \mathrm{M} \otimes \\
25<50 \mathrm{M} \otimes\end{array}$ & \\
\hline \multicolumn{3}{|c|}{\begin{tabular}{l|lll} 
Previous & 1 & Next
\end{tabular}} & of 5 entries \\
\hline
\end{tabular}

Gambar 3. Data Sub Kriteria

Pada gambar 2 data subkriteria dengan bobot subkriteria ditentukan berdasarkan data analisis dengan metode smart yang digunakan sebagai bobot penilaian kelayakan seleksi penerima bantuan pengembangan usaha pangan masyarakat.

\begin{tabular}{|c|c|c|c|c|c|c|c|c|c|}
\hline \multicolumn{9}{|c|}{ Eksekusi Perangkingan } & Kembali \\
\hline Show & 10 & entries & & & & \multicolumn{4}{|c|}{ Search: } \\
\hline $\mathrm{Na}$ & \multicolumn{2}{|c|}{ Alternatif } & Legalitas & $\begin{array}{l}\text { Pengalaman } \\
\text { Kegiatan } \\
\text { Dagang }\end{array}$ & $\begin{array}{l}\text { Memiliki } \\
\text { AD/ART }\end{array}$ & $\begin{array}{l}\text { Ketersediaan } \\
\text { Mesin }\end{array}$ & $\begin{array}{l}\text { Luas Gudang } \\
\text { Penyimpanan }\end{array}$ & Hasil & Keterangan \\
\hline- & \multicolumn{2}{|c|}{ Bobot } & 0.3 & 0.4 & 0.15 & 0.1 & 0.05 & - & - \\
\hline 1 & \multicolumn{2}{|c|}{$\begin{array}{l}\text { Kelompok Tani Karya } \\
\text { Bersama }\end{array}$} & 30 & 30 & 9 & 10 & 3.75 & 82.75 & $\begin{array}{l}\text { Sangat } \\
\text { Layak }\end{array}$ \\
\hline 2 & \multicolumn{2}{|c|}{$\begin{array}{l}\text { Kelompok Tani Usaha } \\
\text { Mandiri }\end{array}$} & 30 & 20 & 9 & 10 & 5 & 74 & Layak \\
\hline 3 & \multicolumn{2}{|c|}{$\begin{array}{l}\text { Kelompok Tani Rukun } \\
\text { Tani }\end{array}$} & 30 & 40 & 9 & 10 & 5 & 94 & $\begin{array}{l}\text { Sangat } \\
\text { Layak }\end{array}$ \\
\hline \multicolumn{8}{|c|}{\begin{tabular}{l|l|l} 
Previous & 1 & Next
\end{tabular}} & \multicolumn{2}{|c|}{ Showing 1 to 4 of 4 entries } \\
\hline
\end{tabular}

Gambar 4. Proses Perangkingan

Dari proses pengolahan data kriteria dan alternatif yaitu kelompok tani yang ada di kota lubuklinggau maka diperoleh proses perangkingan berdasarkan bobot kriteria dan subkriteria sehingga menghasilkan perangkingan dimana pada sistem yang telah dibangun memperoleh informasi penilaian terhadap kelompok tani yang sangat layak untuk menerima bantuan pengembangan usaha pangan adalah kelompok tani rukun tani dan karya bersama sedangkan yang layak adalah kelompok tani usaha mandiri.

\section{KESIMPULAN DAN SARAN}

Dengan menggunakan metode Simple Multy Atributte Rating Technique dapat diketahui hasil perhitungan bahwa gabungan kelompok tani yang sangat layak untuk mendapatkan bantuan dana pengembangan usaha pangan masyarakat adalah gabungan kelompok tani rukun tani dengan penilaian akhir 94 dengan rekomendasi sangat Layak dan dikuti hasil penilaian kelompok tani karya bersama dan usaha mandiri. Selain itu penentuan bobot yang tepat pada setiap kriteria sangat mempengaruhi hasil 
perhitungan terhadap rekomendasi pemberian bantuan dana pengembangan usaha pangan masyarakat. Untuk dapat memperoleh hasil yang lebih akurat maka perlu dilakukan uji validitas terhadap kriteria untuk memperoleh kriteria yang lebih tepat sesuai dengan kebutuhan seleksi kelayakan penerima bantuan pengembangan usaha pangan masyarakat.

\section{UCAPAN TERIMA KASIH}

Terima kasih pada semua pihak baik secara personal dan kelembagaan yang telah berkontribusi dalam pelaksanaan penelitian ini.

\section{DAFTAR PUSTAKA}

Aziz, Yusuf., Agus, Purwoko., I. (2018). Partisipasi Peserta dan Kinerja Kelompok Tani Program Pengembangan Usaha Pangan Masyarakat. Retrieved from Repository UNIB website: http://repository.unib.ac.id/id/eprint/17518

Arni, A., Apriadi, D. (2019). Sistem Pendukung Keputusan Pembukaan Jaringan Trayek Angkutan Kota Dengan Metode Simple Additive Weighting, Jurnal Ilmiah Binery, 1(1), pp. 29-35.

Badan Ketahanan Pangan Kementrian Pertanian. (2016). Pedoman Pelaksanaan Kegiatan Pengembangan Usaha Pangan Masyarakat. Jakarta.

Budiman, H,D. (2013). Sistem Pendukung Keputusan Anggota Kepolisian Terhadap Calon Seleksi Alih Golongan (SAG) Menggunakan Metode SMART. Skripsi. Program Studi Ilmu Komputer Fak. MIPA Universitas Pendidikan Indonesia

Cholil, R.S., Pinem, R.P.A., Vydia, V. (2018). Implementasi Metode Simple Multi Attribute Rating Technique untuk Penentuan Prioritas Rehabilitasi dan Rekonstruksu Pasca Bencana Alam, Jurnal Ilmiah Teknologi Sistem Informasi, 4(1), pp. 1-6.

Faizal, Fatma A.S., Muhammad., D. (2017). Implementasi Sistem Pendukung Keputusan dengan Metode Smart untuk Merangking Kemiskinan dalam Proses Penentuan Penerimaan Bantuan PKH, Jurnal Coding Sistem Komputer Untan, 5(2), pp. 13-24.

Lubuklinggau, (2012). Perda Kota Lubuklinggau No 1 Tahun 2012 tentang Rencana Tata Ruang Wilayah Kota Lubuklinggau 2012-2032, Lubuklinggau.

Mesran., Pristiwanto., Sihombing., D., (2018). Implementasi Metode Electre dalam Menentukan Rice Cooker Terbaik, Jurnal Telematika, 11(2), pp. 43-54.

Novianti, D., Astuti, I.F., dan Khairina, D.M., (2016). Sistem Pendukung Keputusan Berbasis Web Untuk Pemilihan Café Menggunakan Metode Smart (Simple Multi-Attribute Rating Technique), Prosiding Seminar Sains dan Teknologi FMIPA Unmul, ISBN:978-602-726581-3, pp. 461-465.

Saputra, A.Y., dan Mawartika, Y.E.B., (2019). Sistem Pendukung Keputusan Dalam Memilih Lokasi Perumahan dengan Metode Simple Multi Attribut Rating Technique, Cogito Smart Journal, 5(1), pp. 35-44. 
Sukmawati, R., Dewi, E.K., dan Indriati, R., (2016). Implementasi Metode SMART untuk Indetifikasi Perkembangan Anak dalam Mengikuti Ekstra, Jurnal Nusantara Of Enginering, 3(1), pp. 5963

Suryanto., Safrizal, M., (2015). Sistem Pendukung Keputusan Pemilihan Karyawan Teladan dengan Metode Simple Multy Atribute Rating, Jurnal CoreIT, 1(2), pp. 25-29.

Sesnika, N., Desi, A., Rusdi. (2016). Aplikasi Sistem Pendukung Keputusan Pemilihan Gedung Serbaguna di Kota Bengkulu Menggunakan Metode Smart, Jurnal Rekursif, 4(1), pp. 30-44.

Santoso, I.S. (2017). Perancangan Sistem Pendukung Keputusan Pemilihan Sekolah Paud menggunakan Metode Smart, Konferensi Nasional Sistem dan Informatika STMIK STIKOM Bali, 10 Agustus 2017.

Yanto, R., (2019). Sistem Pendukung Keputusan Seleksi Proposal Penerapan Iptek Bagi Masyarakat, Jurnal Digital Zone, 10(1), pp. 77-87. 